\title{
Cell proliferation in ovarian follicles from Bos taurus indicus females with different antral follicle count
}

\author{
Fernanda Zandonadi Machado, Larissa Zamparone Bergamo, Camila Bizarro-Silva, Fábio Morotti, Katia \\ Cristina Silva-Santos, Marcelo Marcondes Seneda ${ }^{1}$
}

Laboratory of Animal Reproduction, University of Londrina. DCV / CCA / UEL. 86057-970, Parana, Brazil.

\begin{abstract}
The aim of this study was to compare the cell proliferation rate of follicles from Bos taurus indicus females with different antral follicle counts (AFCs). Thirty pairs of ovaries were classified as having low ( $\leq 31$ follicles), intermediate $(\geq 46$ and $\leq 76$ follicles) or high AFC $(\geq 91$ follicles). The ovaries were cut into $1 \mathrm{x}$ $1 \times 0.3 \mathrm{~cm}$ fragments, fixed in $10 \%$ buffered formalin solution and subjected to immunohistochemical analysis for proliferating cell nuclear antigen (PCNA). PCNA detection was detected in all stages of follicular development, being 1,388 (82.23\%) primordial, 197 $(11.67 \%)$ primary, $29(1.72 \%)$ secondary and 74 $(4.83 \%)$ antral follicles. The PCNA detection rate was higher $(\mathrm{P} \leq 0.05)$ for antral and secondary follicles in ovaries with intermediate and low AFCs. This study showed that higher PCNA at early stages of follicular growth is detected in animals with high AFC, whereas a higher PCNA is seen in secondary and antral follicles of animals with low AFC.
\end{abstract}

Keywords: bovine, follicular development, immunohistochemistry, ovaries, PCNA.

\section{Introduction}

The antral follicle count (AFC) is a remarkable reproductive feature that can be determined quickly and accurately. Therefore, after an ultrasound examination, females can be classified into groups defined in number by a low, intermediate or high antral follicles Some studies have been proposed to elucidate the influence of AFC on the fertility of cows because the number of antral follicles in the same animal is highly repeatable (Burns et al., 2005; Ireland et al., 2007, 2008, 2009; Silva-Santos et al., 2014). The AFC in Bos taurus is directly correlated with the ovarian follicular reserve (Ireland et al., 2011), but this relationship has not been fully elucidated in Bos taurus indicus females. Bos taurus indicus females have a higher population of antral follicles than Bos taurus (Batista et al., 2014), generating a greater number of viable oocytes (Pontes et al., 2011).

Mossa et al. (2012) reported that Bos taurus cows with low AFCs have lower fertility than those with high AFCs. In addition, they reported a positive correlation between high AFC, and better reproductive efficiency in several aspects studied. However, recent studies have revealed different patterns in Zebu cattle. When comparing pregnancy rates after artificial insemination, Bos taurus indicus cows with low AFCs presented better results, while females with high AFCs showed lower pregnancy rates (Santos et al., 2012, 2013; Morotti et al., 2014; Santos et al., 2016).

Considering the contrast between practical aspects, such as pregnancy rates, described in those reports, it would be interesting to evaluate the physiological mechanisms of ovarian activity according to the AFC. Proliferating cell nuclear antigen (PCNA) is a protein that plays an essential role in regulating cellular functions of eukaryotic organisms (Strzalka et al., 2015). It is well established that the PCNA is a marker for cellular proliferation and is associated with DNA synthesis in all eukaryotic species that include Bos taurus indicus (Strzalka and Ziemienowicz, 2007; Sun et al., 2012). In this way, the investigation of PCNA activity on follicular activity in cattle ovaries should contribute to clarify the controversial aspects mentioned above, mainly in Bos indicus females.

Therefore, the aim of this study was to evaluate the cell proliferation of follicles from Bos taurus indicus females with a low, intermediate or high antral follicle count.

\section{Material and methods}

\section{Ovaries}

Ovaries $(\mathrm{n}=60)$ from cyclic (presence of corpus luteum) Nelore (Bos taurus indicus) cows $(\mathrm{n}=30), 72$ to 96 months of age, with a body condition score (BCS) from 4 to 4.5 (scale of 1 to 5; Lowman et al., 1976) were obtained from a local slaughterhouse (latitude $23^{\circ} 17^{\prime}$ 34 " S and longitude $51^{\circ} 10^{\prime} 24^{\prime}$ W), and transported to the laboratory within 20 minutes. The ovaries were placed in pairs, separated by animal, and transported in an insulated box with $\mathrm{NaCl} 0.9 \%$ solution at $30^{\circ} \mathrm{C}$. At the laboratory, each pair of ovaries was placed in a container with $\mathrm{NaCl} 0.9 \%$ solution, and the $\mathrm{AFC}$ was assessed by the same operator using a real-time Bmode ultrasound scanner (Scanner 200 Vet; Pie Medical, Maastricht, The Netherlands). All antral follicles ( $\geq 2 \mathrm{~mm}$ in diameter) were identified and counted. Considering the AFC average and standard deviations, each pair of ovaries was classified into one of three groups: low $(\leq 31$ follicles, $n=6)$, intermediate

${ }^{1}$ Corresponding author: mseneda@uel.br

Phone: +55(43)3371-5622

Fax: +55(43)3371-4063.

Received: December 16, 2016

Accepted: November 12, 2017 
( $\geq 46$ and $\leq 76$ follicles, $\mathrm{n}=16$ ) and high $\mathrm{AFC} \geq 91$ follicles, $\mathrm{n}=8$ ).

\section{Histological processing}

The AFC were classified in categories. Fifteen pairs of ovaries were designated for histological processing ( $\mathrm{n}=5$ ovaries for each AFC group). We excluded those pairs of ovaries $(n=15)$ whose AFC did not meet the criteria described above. Only one ovary from each pair was selected according to the absence of a corpus luteum and/or pre-ovulatory follicle. The selected ovaries were cut into fragments approximately $1 \times 1 \times 0.3 \mathrm{~cm}$, and then fixed in $10 \%$ buffered formalin solution for 8 hours. Subsequently, these fragments remained in $70 \%$ alcohol for 24 hours, after being dehydrated in increasing concentrations of alcohol, diaphanized in xylene, and embedded in paraffin blocks included in histological sections. The serial sections, 5$\mu \mathrm{m}$ thick, were cut on the microtome (Leica ${ }^{\circledR}$, WetzlarGermany). The slides were processed for staining with hematoxylin and PAS. The best fragments were designed for immunohistochemical assessment of proliferative activity using PCNA.

\section{Immunohistochemistry}

Cell proliferation was evaluated by immunohistochemical staining technique using the detection of PCNA. We used the mouse anti-PCNA (monoclonal antibody clone $\mathrm{PC} 1 \mathrm{O}$, Novex ${ }^{\circledR}, 1: 100$ dilutions) primary antibody and anti-mouse goat (Invitrogen, 1:100 dilution) secondary antibody. The positive control was skin cancer and negative control was performed with the absence of primary antibody. Both positive and negative controls were used according to the manufacturer's instructions, following the same dilutions used in the experimental samples.

Histological sections were deparaffinized, rehydrated and subjected to antigenic recovery in trisEDTA Tween solution ( $\mathrm{pH}$ 9.0) with incubation in an electric pressure cooker for about nine minutes. Subsequently, the sections were subjected to blocking of endogenous peroxidase with 10 volumes of hydrogen peroxide $(3 \%)$ for 30 minutes, and blocking of nonspecific reaction with the membrane blocking solution (Invitrogen TM) for 30 minutes. Thus, they were incubated with primary antibody anti-PCNA overnight (18 hours) at $4^{\circ} \mathrm{C}$ on a rocker. After incubation, the secondary antibody was applied for 30 minutes, and then the reaction was revealed using diaminobenzidine substrate (DAB) in a brown color in approximately 5 minutes. Subsequently, the material was stained with Harris Hematoxylin, dehydrated, and the slides were mounted to analyzed under a light microscope (Nikon $\AA$, Tokyo, Japan).

Follicles were classified according to the stage of development, considering the shape, and layers of the granulosa cells (GC), as follows: primordial (oocyte surrounded by a flat granulosa cell layer); primary (one layer of cuboidal granulosa cells); secondary (two or more layers of cuboidal cells); or antral (three or more layers of cuboidal granulosa cells and the presence of antrum) according Silva-Buttkus et al. (2008).

\section{Statistical analysis}

The mean number and standard deviation (SD) were extracted from the total population of antral follicles from all 60 ovaries. The low AFC group was determined based on the population mean $\approx\left(\begin{array}{ll}6 & 1\end{array}\right.$ follicles) minus the $\mathrm{SD}(\approx 30$ follicles) (Low $\mathrm{AFC} \leq 31$ follicles; $n=6)$. The intermediate group was within the range of $\geq 46$ and $\leq 76$ follicles $(n=16)$. The high AFC group was based on the population mean plus the SD value (High $A F C \geq 91$ follicles; $n=8$ ). The data were presented as proportions for the descriptive statistical analyses. The Fisher's exact test was used to evaluate the difference in the percentage of immunostained follicles among AFC groups (high, intermediate and low count). The statistical analyses were performed using Minitab ${ }^{\circledR}$ statistical 16.1.1 software, and a $p$ value $\leq$ 0.05 indicated a significant difference.

\section{Results}

A total of 1,688 follicles were evaluated by staining of PCNA in Bos taurus indicus females with low, intermediate and high AFCs. We classified 1,388 $(82.23 \%)$ follicles as primordial, $197(11.67 \%)$ as primary, $29(1.72 \%)$ as secondary and $74(4.83 \%)$ as antral follicles (Table 1). Considering the comparison among the AFC groups (low versus intermediate versus high), primordial follicles from cows with a high AFC showed a higher $(\mathrm{P} \leq 0.05)$ PCNA detection rate compared to the intermediate group. However, secondary and antral follicles had higher $(\mathrm{P} \leq 0.05)$ PCNA detection rates in the groups with intermediate and low AFCs.

Table 1. Percentage of follicles stained for proliferating cell nuclear antigen from bovine females with high (AFC $\geq 91$ follicles), intermediate $(\geq 46$ and $\leq 76$ follicles) and low antral follicle counts ( $\leq 31$ follicles).

\begin{tabular}{lcccc}
\hline Follicles & High & Intermediate & Low & Total \\
& $\%(\mathrm{n})$ & $\%(\mathrm{n})$ & $\%(\mathrm{n})$ & $82.23(1,388)$ \\
\hline Primordial & $85.60^{\mathrm{a}}(1,177)$ & $63.09^{\mathrm{b}}(94)$ & $71.34^{\mathrm{ab}}(117)$ & $11.67(197)$ \\
Primary & $11.13^{\mathrm{a}}(153)$ & $15.44^{\mathrm{a}}(23)$ & $12.80^{\mathrm{a}}(21)$ & $1.72(29)$ \\
Secondary & $1.16^{\mathrm{b}}(16)$ & $4.70^{\mathrm{a}}(7)$ & $3.66^{\mathrm{a}}(6)$ & $4.83(74)$ \\
Antral & $2.11^{\mathrm{b}}(29)$ & $16.75^{\mathrm{a}}(25)$ & $12.20^{\mathrm{a}}(20)$ & 1688 \\
\hline Total & 1375 & 149 & 164 & 164
\end{tabular}

Values withdifferent superscripted letters within the same rows (comparing AFC groups) indicate statistical difference $(\mathrm{P} \leq 0.05)$. 
The PCNA detection observed in primordial and primary follicles was restricted to the oocyte. The PCNA signal in secondary and antral follicles was identified in the oocyte as well as in the granulosa and theca. In follicles with only a few layers of granulosa and a small number $(<10)$ of stained cells, there was no staining on theca cells. On the other hand, in those follicles with more layers of granulosa and theca cells, we easily found stained cells in the theca layers, a situation also observed in tertiary and large antral follicles (Fig. 1).
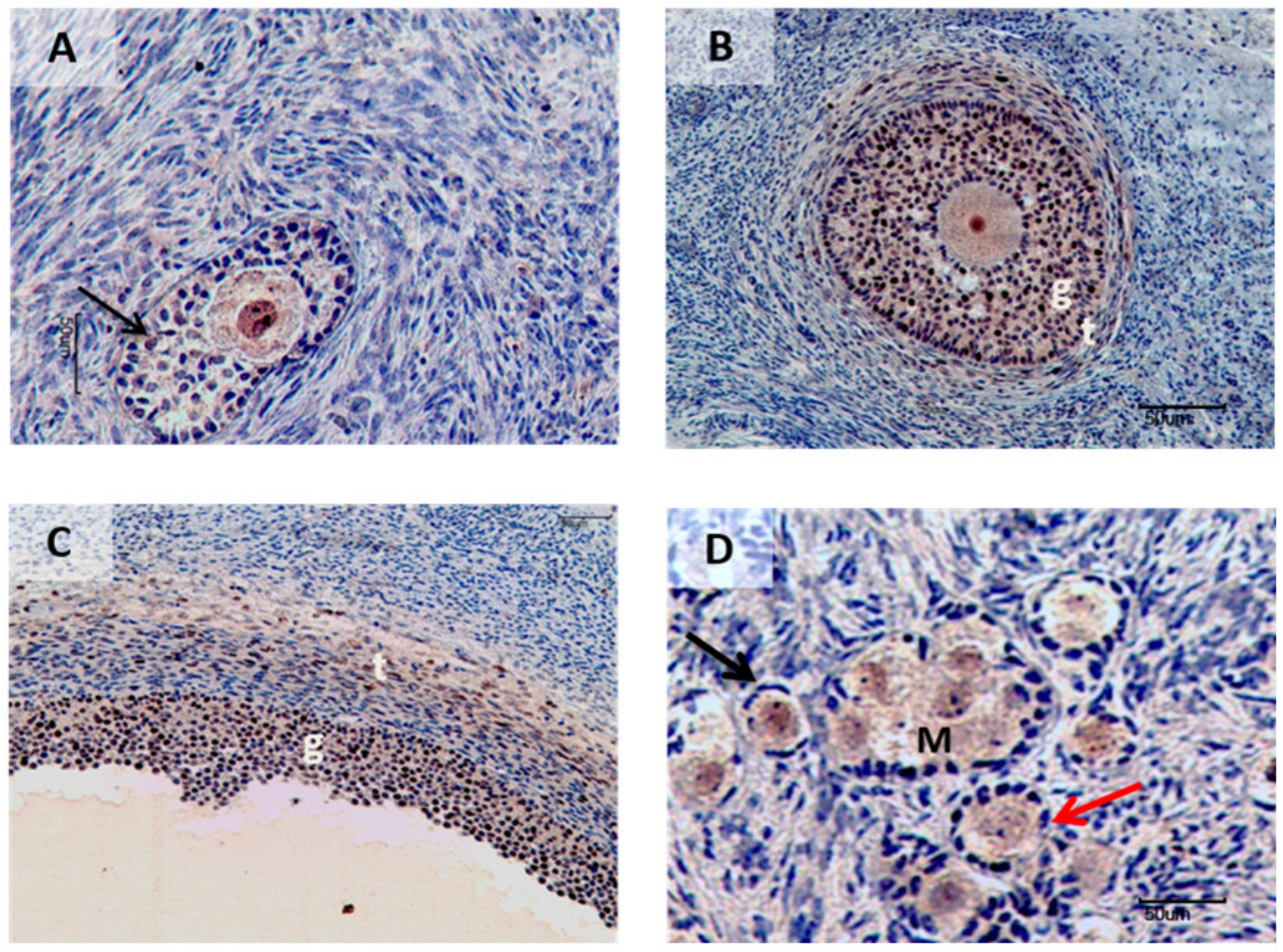

Figure 1. Ovarian follicles of Bos taurus indicus females marked in brown color for the proliferating cell nuclear antigen. A - Detection of proliferating cell nuclear antigen in nucleus, cytoplasm and granulosa cells (arrow) in initial secondary follicle. B - Detection of proliferating cell nuclear antigen in nucleus, cytoplasm, granulosa cells $(\mathrm{g})$ theca $(\mathrm{t})$ in secondary follicle. C - Layers of granulosa $(\mathrm{g})$ and theca $(\mathrm{t})$ of antral follicle. D - Detection of proliferating cell nuclear antigen in nucleus and cytoplasm of primordial follicles (black arrow), primary (red arrow), and detection of proliferating cell nuclear antigen in multioocytes (M).

\section{Discussion}

The follicular cell proliferation was evaluated using the anti-proliferating cell nuclear antigen antibody according to the antral follicle population in cattle. We identified a higher proliferative activity in the final stages of follicular development from females with intermediate and low AFCs.

The present study is based on the principle that each cow can be classified according to the number of antral follicles in the ovaries. In performing just one ultrasound examination, there is a high repeatability for classifying females as having a low, intermediate or high AFC (Ireland et al., 2007, 2008; Mossa et al., 2010; Silva-Santos et al., 2014).

In studies carried out with Bos taurus indicus females, a positive correlation between high AFC and better reproductive efficiency was described (Ireland et al., 2007; 2008; Evans et al., 2012), and a low AFC was associated with poor fertility (Mossa et al., 2012). However, several studies performed in Bos taurus indicus cattle submitted to fixed time artificial insemination (FTAI) showed better pregnancy rates in females with a low AFC (Santos et al., 2013; Morotti et al., 2014; Santos et al., 2016). Interestingly, there is a larger follicular diameter in females with low AFC (Santos et al., 2012; Morotti et al., 2016). This information is relevant because larger ovulatory follicles have been associated with better conception rates in FTAI programs (Perry, 2007; Meneghetti et al., 2009). Our results on cell proliferation indicated a more intense follicular activity in cows with a low AFC, at least for follicles at the final stages of development. This finding is in accordance with those aspects mentioned above, regarding better rates of pregnancy for Bos taurus indicus cows with a low AFC.

In the present study, theca cells of secondary and antral follicles showed staining for PCNA, which is in accordance with previous studies that demonstrated a PCNA signal in different stages of follicular growth, mainly after the primordial stage (Oktay et al., 1995; Wandji et al., 1996; Tománek and Chronowska, 2006). The PCNA staining for proliferative activity is closely related to cellular activity for DNA repair, and cell division (Myoung et al., 2006; Strzalka and Ziemienowicz, 2011).

Comparing the same follicular category among AFC groups, the present study showed that animals with 
intermediate or low AFCs showed more intense staining indicative of cell proliferation in the secondary, and antral follicular stages than those with a high AFC. On the other hand, animals with a high AFC showed a higher cell proliferation rate in the early stages of follicular growth. Therefore, we identified a distinct pattern of cell proliferation in the follicular stages that varies according to the $\mathrm{AFC}$.

A clear connection between AFC and fertility remains contradictory in cattle. Considering Zebu cattle, some articles presented data favoring low AFC (Santos et al., 2013; Morotti et al., 2014; Santos et al., 2016). However, others teams showed best fertility rates for high AFC in European breeds (Ireland et al., 2007; 2008; Evans et al., 2012). The majority of the articles focused only on pregnancy rates, hormonal dosage or embryo production and not on follicular activity. We believe that our data with PCNA activity are bringing an important novelty for a better comprehension on the matter, mainly considering the distinct pattern of staining we described in the results.

In conclusion, the cell proliferation evaluated by immunostaining for proliferating cell nuclear antigen differs between follicular categories, with a higher proliferation rate in groups with intermediate and low antral follicle counts.

\section{Acknowledgements}

Authors thank Brazilian Council for Scientific and Technological Development (CNPq), and Coordination for the Improvement of Higher Education Personnel by providing financial support.

\section{References}

Batista EOS, Macedo GG, Sala RV, Ortolan, MDDV, Sá Filho MF, Del Valle TA, Jesus EF, Lopes RNVR, Renno FR, Baruselli PS. 2014. Plasma Antimullerian Hormone as a Predictor of Ovarian Antral Follicular Population in Bos indicus (Nelore) and Bos taurus (Holstein) Heifers. Reprod Domest Anim, 49:448-452.

Burns DS, Jimenez-Krassel F, Ireland JLH, Knight PG, Ireland JJ. 2005. Numbers of antral follicles during follicular waves in cattle: Evidence for high variation among animals, very high repeatability in individuals, and an inverse association with serum follicle-stimulating hormone concentrations. Biol Reprod, 73:53-62.

Evans ACO, Mossa F, Walsh SW, Scheetz D, Jimenez-Krassel F, Ireland JLH, Smith GW, Ireland JJ. 2012. Effects of maternal environment during gestation on ovarian folliculogenesis and consequences for fertility in bovine offspring. Reprod Domest Anim, 47:31-37.

Ireland JJ, Smith GW, Scheetza D, Jimenez-Krassel F, Folgera JK, Ireland JLH, Mossa F, Lonergan P, Evans AC. 2011. Does size matter in females? An overview of the impact of the high variation in the ovarian reserve on ovarian function and fertility, utility of anti-Müllerian hormone as a diagnostic marker for fertility and causes of variation in the ovarian reserve in cattle. Reprod Fert Develop, 23:1-14.

Ireland JJ, Ward F, Jimenez-Krassel F, Ireland JLH, Smith GW, Lonergan P, Evans ACO. 2007. Follicle numbers are highly repeatable within individual animals but are inversely correlated with FSH concentrations and the proportion of good-quality embryos after ovarian stimulation in cattle. Hum Reprod, 22:1687-1695.

Ireland JJ, Zielak AE, Jimenez-Krassel F, Folger J, Bettegowda A, Scheetz D, Walsh S, Mossa F, Knight PG, Smith GW, Lonergan P, Evans ACO. 2009. Variation in the ovarian reserve is linked to alterations in intrafollicular estradiol production and ovarian biomarkers of follicular differentiation and oocyte quality in cattle. Biol Reprod, 80:954-964.

Ireland JLH, Scheetz D, Jimenez-Krassel F, Themmen APN, Ward F, Lonergan P, Smith GW, Perez GI, Evans ACO, Ireland JJ. 2008. Antral follicle count reliably predicts number of morphologically healthy oocytes and follicles in ovaries of young adult cattle. Biol Reprod, 79:1219-1225.

Lowman BG, Scott NA, Somerville SH. 1976. Condition scoring beef cows. The East of Scotland College of Agriculture Bulletin. 6, 8p.

Meneghetti M, Sá Filho OG, Peres RF, Lamb GC, Vasconcelos JL. 2009. Fixed-time artificial insemination with estradiol and progesterone for Bos indicus cows I: basis for development of protocols. Theriogenology, 72:179-189.

Morotti F, Santos GMG, Silva-Santos KC, Moritz Y, Marcantonio T, Seneda MM. 2014; abstract. Follicular dynamics in Nelore females (Bos indicus) with high or low numbers of antral follicles. Anim Reprod, 11:352.

Morotti F, Santos GMG, Silva-Santos KC, Ferri F, Seneda MM. 2016; abstract. Effect of high and low antral follicle count on the growth rate and follicular diameter from Nelore (Bos indicus) cows subjected to synchronization of ovulation. Anim Reprod, 13:519.

Mossa F, Walsh SW, Butler ST, Berry DP, Carter F, Lonergan P, Smith GW, Ireland JJ, Evans ACO. 2012. Low numbers of ovarian follictes $3 \mathrm{~mm}$ in diameter are associated with low fertility in dairy cows. J Dairy Sci, 95:2355-2361.

Mossa F, Jimenez-Krassel F, Folger JK, Ireland JL, Smith GW, Lonergan P, Evans ACO, Ireland JJ. 2010. Evidence that high variation in antral follicle count during follicular waves is linked to alterations in ovarian androgen production in cattle. Reproduction, 140:713-720.

Myoung H, Kim MJ, Lee JH, Ok YJ, Paeng JY, Yun PY. 2006. Correlation of proliferative markers (Ki-67 and PCNA) with survival and lymph node metastasis in oral squamous cell carcinoma: a clinical and histopathological analysis of 113 patients. Inter. J Oral Max Surg, 35:1005-1010.

Oktay K, Schenken RS, Nelson JF. 1995. Proliferating cell nuclear antigen marks the initiation of follicular growth in the rat. Biol. Reproduction, 53:295-301.

Perry GA, Smith MF, Roberts AJ, Macneil MD, Geary TW. 2007. Relationship between size of the 
ovulatory follicle and pregnancy success in beef heifers. J Anim Sci, 85:684-689.

Pontes JHF, Melo-Sterza FA, Basso AC, Ferreira CR, Sanches BV, Rubin KCP, Seneda MM. 2011 Ovum pick up, in vitro embryo production, and pregnancy rates from a large-scale commercial program using Nelore cattle (Bos indicus) donors. Theriogenology, 75:1640-1646.

Santos GMG, Silva-Santos KC, Barreiros TRR, Blaschi W, Morotti F, Silva CB, Moraes FLZ, Giudicissi DPL, Seneda MM. 2013, abstract. Conception rates following FTAI of Nelore cows (Bos indicus) with high, intermediate and low numbers of antral follicles. Anim Reprod, 10:451.

Santos GMG, Silva-Santos KC, Barreiros TRR, Morotti F, Sanches BV, Moraes FLZ, Blaschi W, Seneda MM. 2016. High numbers of antral follicles are positively associated with in vitro embryo production but not the conception rate for FTAI in Nelore cattle. Anim Reprod Sci, 165:17-21.

Santos GMG, Silva-Santos KC, Siloto LS, Morotti F, Marcantonio T, Marinho LSR, Thasmo RLO, Koetz JRC, Cintra DML, Seneda MM. 2012. Dinâmica folicular em fêmeas bovinas de alta, média e baixa contagem de folículos antrais: resultados preliminares. Acta Sci Vet, 40:422.

Silva-Buttkus P, Jayasooriya GS, Mora JM, Mobberley M, Ryder TA, Baithun M, Stark J, Franks S, Hardy K. 2008. Effect of cell shape and packing density on granulosa cell proliferation and formation of multiple layers during early follicle development in the ovary. $J$ Cell Sci, 121:3890-3900.

Silva-Santos KC, Santos GMG, Koetz Junior C, Morotti F, Siloto LS, Marcantonio TN, Urbano MR, Oliveira RL, Lima DCM, Seneda MM. 2014. Antral Follicle Populations and Embryo Production - In Vitro and In Vivo - of Bos indicus-taurus Donors from Weaning to Yearling Ages. Reprod Domest Anim, 49:228-232.

Strzalka WK, Aggarwal C, Krzeszowiec W, Jakubowska A, Sztatelman O, Banas AK. 2015. Arabidopsis PCNAs form complexes with selected Dtype cyclins. Front Plant Sci, 6:1-11.

Strzalka W, Ziemienowicz A. 2007. Molecular cloning of Phaseolus vulgaris cDNA encoding proliferating cell nuclear antigen. J Plant Physiol, 164:209-213.

Strzalka W, Ziemienowicz A. 2011. Proliferating cell nuclear antigen (PCNA): a key factor in DNA replication and cell cycle regulation. Ann Bot-London, 107:1127-1140.

Sun YL, Zhang J, Ping ZG, Wang CQ, Sun YF, Chen L, Li XY, Li CJ, Zhu XL, Liu Z, Zhang W, Zhou X. 2012. Relationship between apoptosis and proliferation in granulosa and teca cells of cystic follicles in sows. Reprod Domest Anim, 47:601-608.

Tománek M, Chronowska E. 2006. Immunohistochemical localization of proliferating cell nuclear antigen (PCNA) in the pig ovary. Folia Histochem Cyto, 44:269-274.

Wandji SA, Srsei V, Voss AK, Eppig JJ, Fortune V. 1996. Initiation in vitro of growth of bovine primordial follicles. Biol Reprod, 55:942-948. 